\title{
Astral Magic and Adelard of Bath's Liber Prestigiorum; or Why Werewolves Change at the Full Moon
}

\author{
Patricia Aakhus ${ }^{1}$
}

\begin{abstract}
Astral magic, the capturing of celestial spirits or rays in engraved stones at astronomically propitious times, enters the West with Adelard of Bath's 12th century translation of Thabit ibn Qurra's treatise on talismanic magic, Liber Prestigiorum. Derived from Greek, Babylonian, Sabian, Egyptian and NeoPlatonic magical theory and practice, astral magic requires profound knowledge of astronomy. Talismans draw down planetary spirits along stellar rays, the vehicles of transmission, following sympathetic correspondences between astronomical and terrestrial phenomena. In the 12th century works Guillaume de Palerne and Le Chevalier au Lion, magic rings and werewolves are tied to astral magic. These works were written for the English court that supported Adelard, and Gervase of Tilbury's Otia Imperialia where 'in England we have often seen men change into wolves according to the phases of the moon' and 'there is no precious stone which may not be consecrated for the exercise of its extrinsic power with the herb of the same name or with the blood of the bird or animal, combined with spells'. Adelard's version of Thabit's text, along with the Latin Picatrix, also derived from Thabit, had the greatest impact on learned magic in the medieval and early modern periods.
\end{abstract}

In the final chapters of the Speculum Astronomiae, Albertus Magnus discusses astronomical texts which he considers abominable. ${ }^{2}$ At the top of his list - in first place - is Adelard of Bath's early twelfth century Liber Praestigiorum. ${ }^{3}$ Attributed to Hermes Trismegistus, it is in fact the

1 Patricia Aakhus sadly died during the editing of these proceedings.

2 Albertus Magnus, Speculum Astronomaie, trans. and ed., Paola Zambelli (Dordrecht: Kluwe Academic Publishers, 1992), [hereafter, Albertus Magnus, Speculum], p. 242.

3 Adelard of Bath, 1080-1152. Born Bath, studied Tours, taught at Laon, spent seven years in Sicily, Syria, Spain before 1116, perhaps before 1109, in Palestine by 1115 . By 1126 in England, translating Arabic astronomical tables of alKhwarizmi; the Liber Prestigiorum comes from the 1120's. It begins: "Ex libris

Patricia Aakhus, ‘Astral Magic and Adelard of Bath's Liber Prestigiorum; or Why Werewolves Change at the Full Moon', eds. Nicholas Campion and Rolf Sinclair, Culture and Cosmos, Vol. 16 nos. 1 and 2, 2012, pp. 151-161. www.CultureAndCosmos.org 
152 Astral Magic and Adelard of Bath's Liber Prestigiorum; or Why Werewolves Change at the Full Moon

first known Hermetic text to enter the west, at the vanguard of translations of Hellenistic and Arabic magic and alchemy which had considerable influence on medieval and renaissance science, philosophy, literature and art. It is found in three manuscripts: two at the Vatican and one in Lyon. ${ }^{4}$ All are bound together with other astrological translations of Adelard: the Ysagoga Minor of Abu Ma'shar, and the pseudoPtolemaic Centiloquium. A twelfth century copy was part of Avranches 235, of the Mont St. Michel scriptorium, but it has gone missing, probably since the early thirteenth century.

While Albertus condemns Adelard's text, he approves of a slightly later translation by John of Seville, of which there are 46 extant copies known, entitled De Imaginibus and attributed to the ninth century Persian mathematician Thabit ibn Quarra. ${ }^{5}$ Both texts begin by declaring that astronomy is the greatest of the liberal arts: 'for the science of the stars is, of all the arts, both the most excellent in its subject and the most useful because of the effect of talismans'. Practitioners of astral magic who are skilled in geometry and philosophy, but lack knowledge of astronomy, are useless.

Adelard states that the successful practitioner must know the precise positions of stars, planets and the moon. This information could be had through consultation of Adelard's 1126 translation of $\mathrm{Al}$ Khwarizmi's star charts and the astrolabe; Adelard dedicated his treatise on its use to his young student Henry II. He needs to know the rulers of the constellations and planetary hours (found in his translation of Abu Ma'shar's Ysagoga Minor) and the influence of planetary spirits upon various animals, vegetables and minerals described in this text and in the contemporary grimoire Picatrix. The knowledgeable astronomer can then make astral talismans and effectively gain the love of a king, a wayward husband or wife, destroy a city, find stolen treasure and rid the city of Bath of scorpions.

Hermetis Liber praestigiorum qui sic incipit: Qui geometrice aut philosophiae peritus expers astronomiae fuerit."

4 Lyons ms. 328 c. 70 r-74r, mss. Pal. Lat 1401, cc 39v-41v, Vat. Lat. 10803, cc $62 \mathrm{v}-66 \mathrm{v}$.

5 The text begins "Dixit Thebit Benchorat: Dixit Aristoteles qui philsophiam." For a list of extant magical texts, incipits and locations see Frank Klaassen pages at Societas Magica website http://www.societasmagica.org/, [accessed 7 December 2010].

Culture and Cosmos 
Albertus does not object to astral magic; what he cannot abide is Adelard's use of suffumigations (incense) and incantations, which suggest that planetary intelligences are being directly addressed. The acceptable De Imaginibus, Albertus explains, 'obtains its virtue solely from the celestial figure.' A talisman is 'engraved under an elected hour; and thus will have a good effect from the celestial virtue by the command of God, because the images found in this sensible world made from the four elements obey the celestial images (the constellations) of the heavens'. ${ }^{6}$ No matter that the mechanism of the cosmos functions identically in both licit and illicit operations; calling down a planetary spirit to inhabit a talisman just seems a bit too much like theurgy. The Hermetic Asclepius, which had been condemned by Augustine, haunted the Middle Ages with the spectre of Egyptian demon worship: making a talisman under correct astronomical conditions in order to attract sympathetic planetary influences was acceptable; drawing a god down into a statue with incense and incantations was not. ${ }^{7}$ Texts like the Liber Praestigiorum, Albertus warns, pretend to be scientific when they are really demonic:

Seven names are engraved or drawn on (talismans) in the correct order to affect a good thing and in inverse order for a thing one wants to be repelled. They are suffumigated with the wood of aloe, saffron and balsam for a good purpose; red sandalwood and resin for an evil purpose...This is the worst kind of idolatry, which, in order to seem credible, observes the 28 mansions of the Moon and the hours of day and night... The names of angels... said to be subservient to the images of the Moon in its orbit, perhaps instead are the names of demons...Spirits are not compelled to act because of these names and fumigations but when God permits it on account of our own sins...they show themselves as if they were compelled to act in order to deceive men. ${ }^{8}$

But unlike the later, fictional, Faust, Adelard of Bath does not consider himself deceived. Astral magic, like Euclid, is science, and along with

6 Albertus Magnus, Speculum, pp. 247-249.

7 Hermetica, trans. Brian Copenhaver (Cambridge: Cambridge University Press, 1992), pp. 80-81.2.

8 Albertus Magnus, Speculum, p. 241. 
154 Astral Magic and Adelard of Bath's Liber Prestigiorum; or Why Werewolves Change at the Full Moon

planetary demons, angels, spirits, sirens, and the lords of the ascendants found in Plato's Timaeus, belonged to Christian cosmology.

The Liber hails astronomy as the greatest of liberal arts and talismanic magic as the most useful part of astronomy. How does talismanic magic work? Adelard first dispenses with the precession of the equinoxes, since astral magic cannot function with disharmony between the visible and astrological constellations: terrestrial lions must obey the celestial lion and the terrestrial scorpions the celestial scorpion, without any sign of advance or retreat. Confidence is essential, since the confident, focused intention of the operator contributes to the power and efficacy of the operation.

The Picatrix, which shares many passages verbatim with the Liber, both being derived from older non-extant texts, explains that planetary spirits invited to enter the talismans travel along rays from the star or planet to the object, and these rays are inextricably linked to aspects of the cosmos: not only to light, colour, sound and incense, but also to the will of the operator. ${ }^{9}$ As a certain image links the planetary spirit to a corresponding animal, vegetable, and mineral, the connection is facilitated by the propitious alignment of planets and constellations, along which the spirit is drawn down into the image of the talisman. This spirit is also the vehicle of transmission, the ray which imprints the planetary image on the parchment, gem or metal talisman. In the human being, the spirit is comprised of celestial matter acquired as the soul, in its incarnation, descends through the planetary spheres. It resides between the soul and senses, in a place where images or phantasms are formed, as in a mirror.

By this mechanism, and by concentrating on an image, practitioners of ars notaria received angelic knowledge. In ceremonial magic images summoned angels or demons to perform certain actions, or to directly invite possession and then (hopefully) exorcism. Giordano Bruno's astrological seals functioned similarly for a different purpose: the formation of memory and perfection of the soul. ${ }^{10}$ The manipulation of spirit and matter under planetary influences is also the goal of the Hermetic art of alchemy. The alchemist extracts the spirit in the processes of calcination, solution and coagulation, in order to bring metals to perfection as gold, and his own soul to perfection. Robert of Chester, who

9 Picatrix, trans. Beatrice Bakhouche (Turnhout: Brepols, 2003) [hereafter Picatrix].

10 Frances Yates, The Art of Memory (London: Peregrine, 1978), pp. 239-259. 
edited Adelard's Liber Lunae, another early text of astral magic, translated The Composition of Alchemy in 1144, the first alchemical text to enter the west.

The Liber moves from the theoretical to the practical. During the engraving, drawing or casting of the talisman or ring, the lord of the horoscope (meaning the planet ruling the zodiac sign containing the ascendant-also called the horoscope in Adelard's translation of Ysagoga Minor) must be benefic, in a fortunate position and free from any unfortunate malefic influences. According to Adelard's Ysagoga Minor, Jupiter, the Sun, Venus, and the Moon are benefic, while Mars and Saturn are malefic.

The materials used to construct the talisman often correspond to the planet whose power is invoked. An appropriate planetary image must be inscribed: for instance, for Venus, a seated woman holding a mirror and a dove, and the image fumigated; Venus prefers frankincense. The power of Jupiter is drawn by the image of a man riding a rooster. As the talisman is finished, prayers or invocations must be addressed to the planetary spirits who are asked to descend from the higher world and be present in order to put into effect, by the power of God, the purpose of the talisman. In the Liber these are quite brief: praise and invitation to come: ' $O$ fugentes istarum stellarum spiritus'. The talisman may then be buried in an appropriate place: the doorway of the house of a desired lover, a graveyard, the middle of a city to be protected or destroyed. Animal blood or body parts may be required, as they are in the Hellenistic Greek Magical Papyrus, or the Hebrew Liber Raziel, which may summon angels, demons or spirits directly, without the aid of talismans. The expected outcomes are the same: gaining the love of an equal, a son, a king and security from his wrath, recovering the love of a husband or wife, causing enmity between individuals, causing war, recovering stolen treasure, increasing wealth, winning a lawsuit, protecting or destroying a place or city, and driving scorpions out of Bath.

In order to drive scorpions from Bath one must inscribe the talisman with 'the name of the ascendant in full along with the name of its lord; and also the names of the lord of the hour-the hour of the Sun, the lord of the day, and also the Moon-it being in Scorpio. Then it should be placed on the back at right angles with the feet twisted back over the head, as if it is stinging itself. Then, when a little stone has been enclosed in its belly, it should be buried in the middle of the place, and during the burial, this prayer should be recited: 'May this species-every 
156 Astral Magic and Adelard of Bath's Liber Prestigiorum; or Why Werewolves Change at the Full Moon

species of its kind-be put to flight from the present place (i.e., from Bath), so that none of them may be able to enter or inhabit it'. ${ }^{11}$ If the incantation is spoken incorrectly or the wrong constellation is ascending, one might actually draw scorpions to Bath in droves. ${ }^{12}$

How was the 'new science' received in the twelfth century? John of Salisbury was traumatized by his teacher, who dipped his fingertips in oil in order to consult spirits, and was horrified to learn that Thomas Beckett consulted a chiromancer. Like his contemporaries Abelard and Heloise, who named their son Astrolabe, Adelard was critical of the conservative French academy and considered himself at the cutting edge of science. His Liber Prestigiorum was followed by translations of Arabic magical texts by Michael Scot and Roger Bacon. Alfonso X, King of Castille and Leon, commissioned translations of the Hebrew Liber Raziel, the Arabic Astromagia, and the Picatrix, the infamous grimoire which shares many spells with the Liber. While the Picatrix greatly influenced Marsilio Ficino, Lorenzo de Medici, Durer, Agrippa, Pico della Mirandola and others of the Humanist movement, sections have only recently been translated into English. ${ }^{13}$

In Questiones Naturales, Adelard mentions that he was a student of magic and had consulted a witch to learn incantations. In an explanation of the concept of 'same and different' from Plato's Timaeus and Aristotle's Physics, he argues that 'the power and efficacy of the green of his emerald ring he wears is stronger than that of his green cloak, although the cloak is much larger'. ${ }^{14}$ The twelfth century lapidary of Marbod of Rennes concurs: the emerald gives its wearer the power of prophecy, persuasive eloquence, and the ability to banish storms and cure

11Charles Burnett, 'Talismans: Magic as Science', in Magic and Divination in the Middle Ages, Texts and Techniques in the Islamic and Christian Worlds (Aldershot: Ashgate, 1996).

12 Picatrix, 2003, p. 191.

13 Anon., Ghayat Al-Hakim. Picatrix: the Goal of the Wise, trans. Hashem Atallah (Seattle: Ouroboros Press, 2002).

14 Questiones naturales, Adelard of Bath. Adelard of Bath, Conversations with his Nephew, trans. Charles Burnett, (Cambridge: Cambridge University Press, 1998), p. 95. "Est etenim hoc pallium meum totum viride, et hec annuli mei smaragdus viridis. Est autem pallii viriditas ad quantitatem maior, smaragdi vero ad efficatiam." This brief excerpt appears in the seventeenth century British Library Ms. Sloane 3826, following Imaginibus and Liber Lunae, attributed in Liber Septem Planetarum Ex Scientia Abel to Adelard of Bath.

Culture and Cosmos 
illness. Although under the influence of Venus, the gem maintains chastity. ${ }^{15}$

The use of engraved gems for medical and other purposes during the twelfth century is demonstrated by the large number of extant engraved gems, lapidaries, and texts of astral magic. In 1176 Louis VIII used gems engraved with images of Abraxas and Diana Venatrix as his official seals: Thomas Beckett's seal had an image of Mercury. In 1200 Gervase of Tilbury wrote that

...there are some who hold magic spells and the power latent in stones to be merely fabulous. But on the evidence of daily experience and also the authoritative writings of the Holy Father, we charge them with lack of faith. Solomon showed how demons could be confined in rings, and summoned out or shut in again by means of seals, signs and spells. For there is no precious stone which may not be consecrated for the exercise of its extrinsic power with the herb of the same name or with the blood of a bird or animal, combined with spells, knowledge of which has come down to us through Solomon. We said extrinsic, and to be sure very many stones share an intrinsic power inherent in them from their own nature, quite apart from what they can do when they have been conjured and consecrated from without. The heliotrope is consecrated with the plant of the same name and then of a truth renders a person invisible. ${ }^{16}$

Stones engraved with planetary images or sigils, like horoscopes, were not seen as occult objects. A benefit of the newly translated Arabic astronomical tables was that the precise positions of the sun, moon, planets and descending and ascending nodes could produce an accurate horoscope. Petrus Alfonso, physician to the English king Henry I, cast horoscopes in order to determine auspicious times for letting blood or performing surgery. As John of Salisbury noted, Thomas Beckett (11621170) consulted a chiromancer who studied the horoscope in his hand. ${ }^{17}$

15 Bruce Knuth, Gems in Myth, Legend and Lore (Jeweler's Press, 1999), pp. 214-215.

16 Gervase of Tilbury, Otia Imperiala, trans. S.E. Banks and J. W. Binns, (Oxford: Clarendon Press, 2002), [hereafter Gervase, Otia], pp. 613-619.

17 Lynn Thorndike, History of Magic and Experimental Science (New York: Columbia University Press, 1923), Vol. 2, p. 167. 
158 Astral Magic and Adelard of Bath's Liber Prestigiorum; or Why Werewolves Change at the Full Moon

John North has identified the collection of Norman horoscopes made for Etienne de Blois and Henry Plantagenet in 1150-51, now in the British Library, as Adelard's work; nine may actually be in his hand. ${ }^{18}$

Elements of Adelard's astral magic appear in the twelfth century works of Chretien de Troyes. The Knight with the Lion wears rings that make him invisible, and protect him from bloodshed and imprisonment. Chretien's Perceval learns the secret name of God found in Adelard's Liber Solis, another treatise on astral magic and in the Liber Razielis translated under the patronage of Alfonso X in Toledo. ${ }^{19}$ Adelard worked with Arabic and Jewish scientists in Salerno, Sicily and Syria. Before 1135 he may have studied with Petrus Alfonsi, who brought Arabic manuscripts from Spain and identified necromancy as the seventh of the liberal arts. ${ }^{20}$

Chretien de Troyes wrote for Marie de Champagne, stepdaughter of Henry II of England, to whom Adelard dedicated his treatise on the astrolabe in 1142. The courts and abbeys of England, Sicily, Spain, and Champagne in France, were closely linked; poets, translators and mathematicians moved between them, creating entertainments, providing horoscopes and medical care. Adelard's associate Robert, bishop of Bath, was the protégé of Henry of Blois, Bishop of Winchester and Abbot of Glastonbury, uncle of Henri of Champagne, husband of Chretien's patroness Marie. Henri's brother, William of the White Hands, Archbishop of Reims, for whom astrological tracts were translated, was served by Gervais of Tilbury.

But why do werewolves change at the full moon? As Gervais writes, 'One thing I know to be of daily occurrence among the people of our country: the course of human destiny is such that certain men change

18 John North, 'Some English Horoscopes', in Adelard of Bath: An English Scientist and Arabist of the Early Twelfth Century, ed. Charles Burnett (London: Warburg Institute, 1987), pp. 147-161.

19 Charles Burnett. 'The Arabic Hermes in the Works of Adelard of Bath' in Hermeticism from Late Antiquity to Humanism, ed. P. Lucentini, I. Parri and V. Perrone Compagni, (Turnhout: Brepols, 2003), [hereafter Burnett, 'Arabic Hermes'], p. 381. Petrus Alfonsi, who worked on the same astronomical tables as Adelard and Robert of Chester, referred to a work containing angelic names revealed by Raziel to Seth. Burnett believes that this may be a version of the Liber Razielis, later translated in Toledo under the patronage of Alfonso X, and the source of names in citation inserted into Adelard's Liber Solis.

20 Charles Burnett, 'Arabic Hermes', p. 381.

Culture and Cosmos 
into wolves according to the cycles of the moon' ${ }^{21}$ The moon's influence was transmitted by rays and precipitation: at the full moon young men stripped, rolled in the dewy grass and turned into werewolves. Engraved rings, incantations and ointments of the Liber Praestigorium are common motifs in the popular werewolf stories of the twelfth century. These werewolves are, by and large, benevolent: the penitent Irish werewolves of Gerald of Wales, outcast heroes of Chretien de Troyes' Knight with the Lion, Marie de France's Bisclavret, and the anonymous Guillaume de Palerne. All were commissioned by the courts of England, Champagne and Sicily, the related abbeys of Reims, Cluny, Bath and Gloucester, an extended family that sponsored the translators of astronomy, mathematics, philosophy and astral magic.

The anonymous Guillaume de Palerne tells the story of a prince turned into a werewolf by a sorceress using an engraved ring, incantations and ointments. ${ }^{22}$ Countess Yolande, who commissioned the work, was married to Hugues IV, the Count of St. Pol, whose grandfather burned down the Abbey of St. Riquier in 1131 with Greek fire, killing a priest saying mass and 2700 others who had fled there for safety. For this he was excommunicated and, according to legend, became a werewolf. ${ }^{23}$ Antimony, an ingredient in 'Greek fire' and an important agent in alchemical transformation, was known as Lupus metallorum or the grey wolf. The transmutation of a man into a wolf, or lead into gold, was held to be a natural, scientific process in twelfth century magical and alchemical texts. All metals in the earth evolved towards gold, signifying perfection and immortality, because gold does not tarnish or decay. The goal of alchemy was not simply the transmutation of base metals, but the perfection of the soul, the redemption of 'fallen matter.' Matter was returned to its primal state during the nigredo stage associated with melancholy, dissolved and coagulated in order to attain a new, purer form. A person suffering from severe melancholy was likely to become a

21 Gervase, Otia, III, p. 87, p. 815.

22 Guillaume de Palerne: An English Translation of the 12th Century French Verse Romance, trans. Leslie Sconduto (Jefferson: McFarland, 2004).

23 Jean-Francois Nieus, Un Pouvoir Comtal Entre Flandre et France: Saint-Pol, 1000-1300 (Bruxelles: de Boeck Universite, 2005). In personal correspondence, Prof. Nieus has found no twelfth century reference to the legend.

Culture and Cosmos 
160 Astral Magic and Adelard of Bath's Liber Prestigiorum; or Why Werewolves Change at the Full Moon

werewolf. It might be necessary for a knight to become a beast, in order to become a more perfect knight.

Albertus concluded his Speculum on Astronomy by recommending a spell for banishing scorpions from Adelard's PseudoPtolomaic Centiloquium:

What cult is shown by this: if in the middle of the place from which you want some species banished, the image is buried with its head downwards and its feet turned upwards? Concerning those books, however, which are truly necromantic...it seems that they ought to be put aside rather than destroyed. For perhaps the time is already at hand, when for certain reasons about which I am now silent, it will be useful on occasion to have inspected them, but nevertheless, their inspectors should be wary of using them. ${ }^{24}$

Despite the scarcity of manuscripts of Adelard's abominable text todayas compared to John of Seville's acceptable version-it is Adelard's that has permeated art and literature from the twelfth century through the early modern period. We see Adelard's influence in the works of Chretien, Ficino, Lorenzo de Medici, Marlowe and Shakespeare. In the visual arts, Dürer's engraving Melancholia contains a magic square of Jupiter derived from Adelard which was meant to counteract the negative effects of Saturn on scholars.

What was abominable about Adelard's text was, in Albertus' words, its 'cultic' or religious character. According to Geoffrey of Monmouth Bladud, the founder of Bath, was a 'clever man who taught necromancy throughout the island of Britain', and 'made hot baths for the use of men, dedicated them to the goddess Minerva and placed inextinguishable fires in her temple'. ${ }^{25}$ There are many votive artefacts in Bath designed to draw the attention of celestial beings. Lastly, perhaps common experience indicates the modern survival of the sensibilities that

24 Albertus Magnus, Speculum, pp. 271-273.

25 Geoffrey of Monmouth, History of the Kings of Britain, trans. Micheal Faletra (Calgary: Boardview Press, 2008), p. 63.

Culture and Cosmos 
guaranteed the appeal of medieval magic: we all know that computers don't work faster when you are desperate, and that the voice inside the GPS device doesn't really care that you are lost; she just recalculates. Intelligences are more comforting than machines when things go badly and perhaps, as Albertus suggested, such things remain useful. 